\title{
Habitat preferences of Bonelli's Eagles Aquila fasciata in Sicily
}

\author{
MASSIMILIANO DI VITTORIO' ${ }^{1}$, MAURIZIO SARẢ ${ }^{1}$ and PASCUAL LÓPEZ-LÓPEZ ${ }^{2 *}$ \\ ${ }^{1}$ Department of Environmental Biology and Biodiversity, University of Palermo, Via Archirafi 18, 93100 Palermo, \\ Italy and ${ }^{2}$ Vertebrate Zoology Research Group, Instituto Universitario de Investigación CIBIO, University of \\ Alicante, Campus San Vicente del Raspeig, Edificio Ciencias III, 03080 Alicante, Spain
}

Capsule For breeding, areas dominated by extensive agricultural and rugged Mediterranean landscapes are preferred; maintenance of habitat heterogeneity and extensive agriculture are key for the conservation of this eagle.

Aims To model breeding habitat preferences of Bonelli's Eagles Aquila fasciata in Sicily, where the last viable population still remains in Italy, in order to identify the most important habitats for conservation.

Methods Pairs were monitored between 1990 and 2010. A case-control design through GLMs was used at two spatial scales: landscape and home-range. Variables included topographic, climatic, land-use, road and descriptors of habitat heterogeneity. Information-based criteria were used to select the best subset of predictors.

Results A total of 22 breeding pairs are still breeding, which represent about the $90 \%$ of the Italian population. The best models at both scales showed that Bonelli's Eagles were clearly associated with Mediterranean features, including rugged areas surrounded by extensive arable land, shrubland and herbaceous vegetation. Our results emphasize the negative effects of habitat fragmentation and agricultural intensification on the probability of occurrence of Bonelli's Eagles.

Conclusion The distribution of Bonelli's Eagles in Sicily can be described by a relatively small number of topographical and land-use variables. The maintenance of habitat heterogeneity is key for the conservation of this endangered raptor.

The knowledge of species distribution patterns and the identification of factors influencing these patterns are crucial in conservation biology (Channell \& Lomolino 2000, Whitfield 2005). In recent years, owing to the broad use of geographical information systems (GIS), the modelling of species distributions has been increasingly used to identify suitable habitat and to predict potential distribution (Robertson et al. 2003, Rushton et al. 2004). Predictive models have been used in many different fields of conservation, with particular emphasis on the investigation of threatened species (Guisan \& Zimmermann 2000). Furthermore, predictive distribution models have important potential applications as they can forecast species occurrence in poorly documented areas, predict the response of a species to changes in land-uses or environmental conditions, or reveal adequate focal areas for conservation

*Correspondence author. Email: Pascual.Lopez@uv.es programmes (Larson et al. 2004, López-López et al. 2006, López-López et al. 2007a, Nams et al. 2006). In the case of Bonelli's Eagles Aquila fasciata, modelling procedures aimed at identifying relationships between habitat features and species occurrence have been largely used to model the species' distribution, mainly in Spain, where it has its main stronghold in Europe (Bustamante \& Seoane 2004, Ontiveros \& Pleguezuelos 2003, Muñoz et al. 2005, López-López et al. 2006, López-López, García-Ripollés \& Urios 2007, Niamir et al. 2011). In addition, habitat selection studies have been focused to account for the influence of habitat composition on population density and productivity (Carrete et al. 2000) or to test the effect of climate on productivity (Ontiveros \& Pleguezuelos 2003).

The fact that ecological patterns depend on the spatial scale at which they are analyzed (Levin 1992, Graf et al. 2005) has become axiomatic, and 
predictive models investigating habitat preferences of species of conservation concern usually employ a multi-scale approach to identify the different factors affecting habitat preferences (Johnson 1980, Store \& Jokimäki 2003). Bonelli's Eagle populations are affected not only by local habitat characteristics but also by historical and environmental factors that are often human-related, which act on larger geographical scales, and the choice of a suitable habitat is probably the result of the integration of different choices at different scales (Martínez et al. 2003, López-López et al. 2006).

Bonelli's Eagles are large-size raptors whose western Palaearctic population is distributed mainly within the circum-Mediterranean area, from Morocco, Algeria and Tunisia, to southern France, Spain, Portugal and southern Italy (Cramp \& Simmons 1980). In recent years this species has suffered a severe population decline in most of its European range (BirdLife International 2004), and has been listed as endangered in Europe (BirdLife International 2011). In Italy, Bonelli's Eagles were recorded in the main islands and in the southern Apennines (Cortone \& Mirabelli 1984, Hagemeijer \& Blair 1997). However, current reproduction in the southern Apennines has not been confirmed and only rare observations have been made in recent years (Cortone \& Di Vittorio, pers. obs.). Although this species was also historically fairly abundant in Sardinia (Arrigoni degli Oddi 1929), it started decreasing in the 1960s, and only three or four pairs remained in the late 1970s (Lo Valvo \& Massa 1992). Currently, it might be still present but there is no certain proof of reproduction (Schenk, pers. comm.). In Sicily, Bonelli's Eagles were regularly recorded as breeders since the 19th century (Doderlein 1869-74, Massa \& Schenk 1983). In the 1960s, the species disappeared from southeast Sicily (Iblean plateau) owing to heavy poaching. Apart from this local decrease, the Sicilian population seemed apparently stable. In the mid-1980s, surveys recorded 17 breeding pairs (Massa 1985). At present, the species breeds regularly in 22 known breeding territories (Di Vittorio 2007), representing nearly 90\% of the entire Italian population (25-28 estimated pairs [Di Vittorio unpub. data]). However, the corresponding density of 1 pair $/ 1155 \mathrm{~km}^{2}$ is much lower than that reported in other European countries (Carrete et al. 2002, Balbontín et al. 2003).

In the present study we have focused on the Bonelli's Eagle population that remains in Sicily, with the aim of modelling habitat preferences to identify the predictors of suitable areas for conservation.

\section{METHODS}

\section{Study area}

Sicily is the largest Mediterranean island (extension $=$ $25.414 \mathrm{~km}^{2}$ ) (Fig. 1). Almost $24.4 \%$ of the territory is mountainous, $61.4 \%$ corresponds to highlands whereas $14.2 \%$ of the surface is lowland. Forests and Mediterranean vegetation, of which almost $6 \%$ burns every year, cover $8.4 \%$ of the surface (Agenzia per la protezione dell'ambiente e per i servizi tecnici [APAT] 2005). The island is also one of the most populated in the western Mediterranean (195 inhabitants per $\mathrm{km}^{2}$ ). There is habitat heterogeneity in areas where cultivation zones (especially arable land) alternate with forest patches of non-native species (Pinus spp. and Eucalyptus spp.), natural woodland (Quercus spp.) and Mediterranean vegetation.

\section{Censuses and study design}

We monitored Bonelli's Eagles from 1990 to 2010, counting 36 different breeding territories, 22 of which were regularly occupied (i.e. those with presence of individuals showing courtship behaviour, breeding attempts and chick-rearing during at least $75 \%$ of the study duration). All territories were visited at least three times during each breeding season. A case-control design was used for modelling (Hosmer \& Lemeshow 2000, Keating \& Cherry 2004). We used two different spatial scales: (1) a 'landscape' scale, encompassing the $10 \times$ $10 \mathrm{~km}$ universal transversal Mercator (UTM) squares where the species was present or absent; and (2) a 'home-range' scale based on the spatial distribution of territories centred on nest-sites. At the landscape scale, 83 occupied UTM squares were compared with 205 unoccupied squares, including bioclimatic, ecological and land-use factors (Table 1). At the home-range scale, we compared the specific habitat composition and topographic factors of those 22 regularly occupied territories versus the same number of unoccupied territories randomly selected.

\section{Measurement of habitat variables at the landscape scale}

The presence/absence of Bonelli's Eagles in UTM squares was obtained from the Atlas of Biodiversity of Sicily (ARPA Sicilia 2008) and specific field surveys (Fig. 1). We used UTM squares because they are a common reference in ornithological studies (Ontiveros 1999, Martínez et al. 2003, Sarà 2008), 


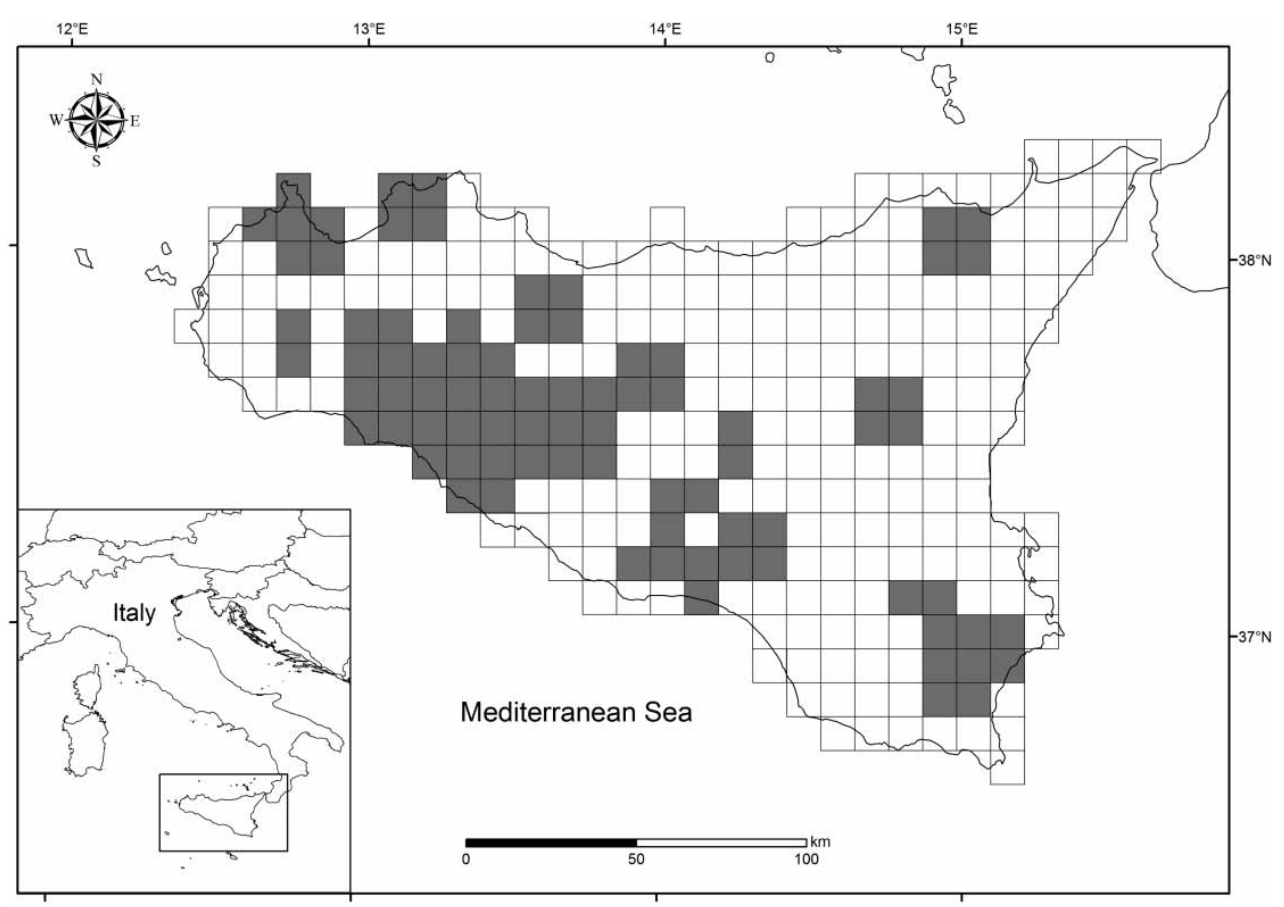

Figure 1. Distribution of Bonelli's Eagle pairs in Sicily, southern Italy.

The $10 \times 10 \mathrm{~km}$ Universal Transversal Mercator squares where the species is present are depicted in grey; location of Sicily within Italy is shown on the inset map.

allowing comparisons with other study areas. The home-ranges of the currently breeding pairs $(n=22)$ and those recently abandoned $(n=14)$ fell within 83 UTM squares (i.e. the cells intersected by the buffer of $4 \mathrm{~km}$ centred on these 36 historic or current sites), and were considered as occupied by Bonelli's Eagles. Then, occupied and unoccupied UTM squares were independently sampled to gather information on 23 variables by using a GIS. The variables included ecological, land-use, bioclimatic and topographic factors, as well as the presence of a potential competitor such as Golden Eagle Aquila chrysaetos in every UTM square (Table 1). There were 17 Golden Eagle territories recorded in Sicily, 12 of which are currently occupied, according to the censuses carried out during the last decade (Di Vittorio 2007, authors unpubl. data). Climatic and land-use variables (4 at the first and 12 at the second level of the Coordination of Information on the Environment (CORINE) land cover (CLC) class codes [European Environmental Agency (EEA) 2000]), were obtained from the database of the Department of Environment and Land Management of Sicily. Topographic variables were obtained from a digital elevation model (DEM) with 20-m pixels of horizontal and vertical resolution.

\section{Measurement of habitat variables at the home-range scale}

Nest-sites and randomly selected unoccupied points were geo-referenced on a digital shape file. Then, we drew a circular plot with radius $4 \mathrm{~km}$ (corresponding to median home-range obtained with telemetry by Bosch et al. 2010) around nest-sites and control points to determine the minimum utilized home-range (Sarà \& Di Vittorio 2003). We did this for two reasons: (1) to calculate the composition of a given habitat feature within each home-range circle; and (2) to avoid overlapping homeranges in the selection of control points. Both occupied $(n=22)$ and randomly selected unoccupied $(n=22)$ plots were independently sampled to gather information on 31 variables using a GIS. The variables included land-use and factors describing habitat composition (Table 1). The land-use variables were obtained from the CORINE land-use map (APAT 2005). All plots were interpolated and processed with the land-cover digital maps of Sicily (scale 1:25 000).

We coded the CLC according to the third hierarchical level (EEA 2000) except for inland waters, which were considered at the second level. The count, perimeter, area and CLC of single patches of all plots were obtained from the same digital map. Seven variables were 
Table 1. Explanatory variables used to characterize the habitat preferences of Bonelli's Eagles in Sicily. The corresponding Coordination of Information on the Environment (CORINE) land cover (CLC) class code at third level is shown in parentheses (EEA 2000).

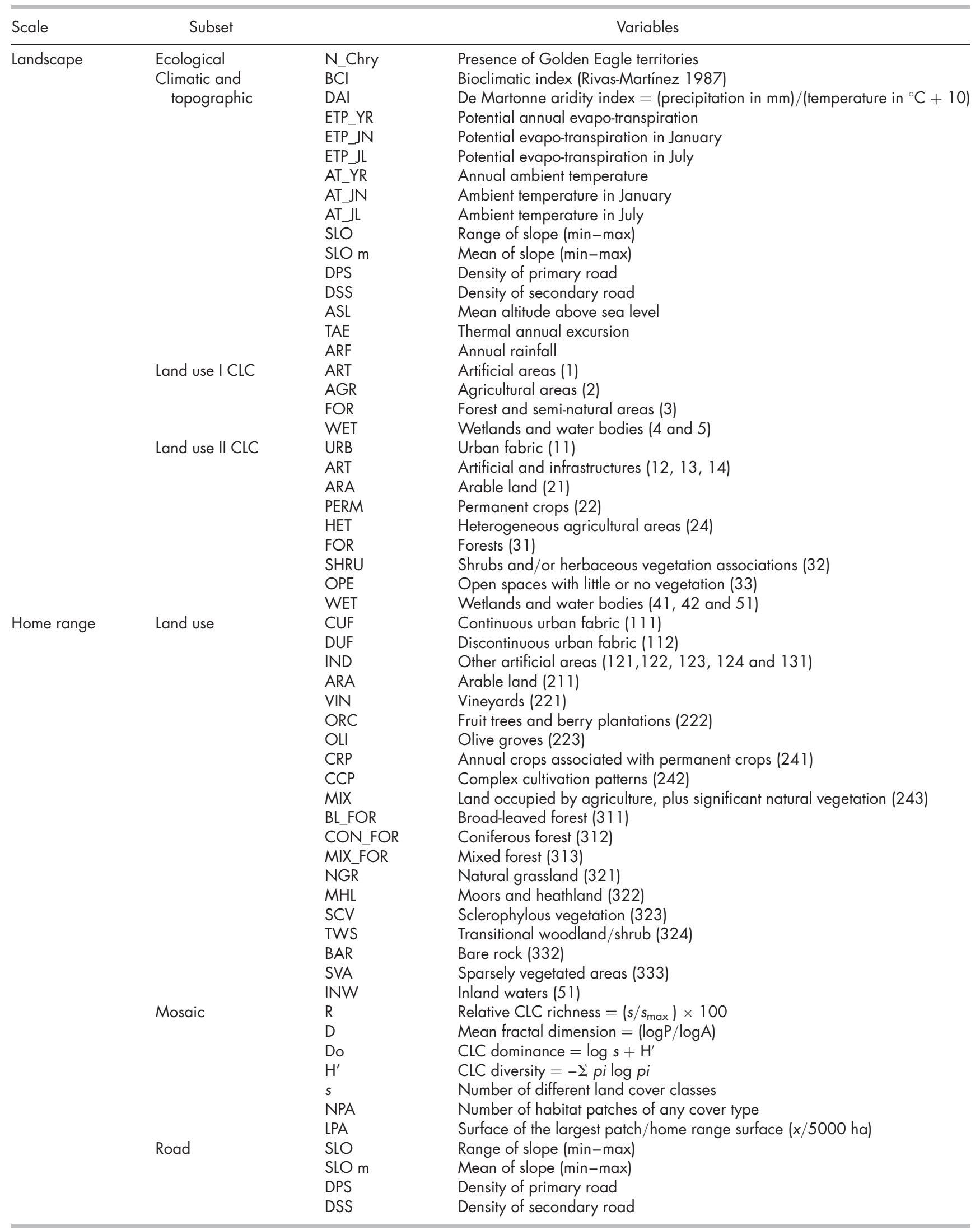


considered in the 'mosaic' subset, including the following indexes: relative CLC richness; fractal dimension; CLC dominance; CLC diversity; number of different CLC classes; number of habitat patches; and surface of the largest patch. Mosaic patterns were extracted using a GIS and were re-drawn from Forman (1995) (see Table 1 for computation details). These variables were calculated considering the number of CLC classes, their extension and the perimeter of every patch contained in all plots, indicating various measures of the type and predominance of boundaries in the landscape. Therefore, these variables can be used as an adequate proxy of spatial heterogeneity and habitat fragmentation in the study area.

\section{Model design and statistical analysis}

We used GLMs to model Bonelli's Eagle habitat preferences in Sicily (Hosmer \& Lemeshow 2000). A forward stepwise regression procedure was performed to test the statistical significance of each variable in turn. This procedure has been commonly used for running predictive models of the distributions of raptors as well in conservation studies (Bustamante 1997, López-López et al. 2006, 2007a). The regression considered every group of variables included in the Table 1 as independent predictors in order to exclude the variables within each subset that did not contribute significantly to the presence of eagles (Wald test: $P>0.05$ ) (Carrete et al. 2007). The dependent binomial variable (i.e. presence/absence of Bonelli's Eagles) was coded as 1/0 and, therefore, a logit-link function and a binomial distribution of error structure were used (McCullagh \& Nelder 1989). We did not perform a global model including all subsets because the introduction of such a large number of predictors is likely to cause over-parameterization and over-fitting problems and, therefore, it is not statistically recommended (Balbontín 2005, LópezLópez et al. 2007b). Environmental variables were standardized to eliminate the effect of differences in the original scale of measurement.

Spatial auto-correlation in environmental variables may bias model parameter estimation, especially when making ecological inference (Legendre \& Legendre 1998). To avoid this, we corrected for the spatial effect by including an spatial term making use of the thirddegree polynomial equation of the central latitude $(x)$ and longitude $(y)$ of each square as follows: $b_{1} x+b_{2} y$ $+b_{3} x^{2}+b_{4} x y+b_{5} y^{2}+b_{6} x^{3}+b_{7} x^{2} y+b_{8} x y^{2}+b_{9} y^{3}$ (Carrete et al. 2007). This cubic trend surface ensures not only that linear gradient patterns will be extracted, but also that more complex features such as patches or gaps, which require quadratic and cubic terms to be correctly described, will also be extracted (Legendre \& Legendre 1998, Carrete et al. 2007). A preliminary forward stepwise regression with the nine terms of the equation as predictor variables and the eagle's presence/absence as the dependent variable was carried out to remove the non-significant spatial terms (Legendre \& Legendre 1998). Next, significant spatial terms $(P<0.05)$ were retained and included with other predictors (i.e. climatic, topographic and landuse) in each model to test if they accounted for a significant change in deviance. Thus, after running independent GLM regressions corrected for spatial autocorrelation, we were able to build three different occurrence models for the landscape scale and two models for the home-range scale. We then repeated the GLM procedure by running the best subset regression option to select the most parsimonious model at every scale. This technique allowed us to further reduce the group of explanatory variables because it found the smallest subset of variables that best predicted the response of a dependent variable by employing the $\mathrm{AIC}_{\mathrm{C}}$ test (AIC corrected for small sample size) (Akaike 1973, e.g. LópezLópez et al. 2007b). Statistical significance was set in all analyses at $P<0.05$. Statistics were computed in Statistica 6.0 (www.statsoft.com).

\section{Hierarchical partitioning and model validation}

The significant terms of the explanatory variables selected in the most parsimonious models were analyzed in order to determine the comparative influence of each variable as well as the separate effect of interactions (Borcard et al. 1992). This analysis was performed at both scales (landscape and home-range). In the former, spatial, climatic, topographic and land-use variables were included, whereas, spatial, mosaic and topographic and road presence variables were included in the latter. The decomposition of the variation into subsets of explanatory variables was carried out by means of a partial regression analysis (Legendre \& Legendre 1998).

Models were validated to assess their predictive power by means of a jackknife randomization procedure (Gotelli \& Ellison 2004). Thus, each model was re-computed deleting systematically one case (an UTM square or a home-range plot), repeating the process as many times as there were observations. The resultant model was applied to the remaining cases to obtain a 
probability on whether or not they could be classified as a Bonelli's Eagle territory, thereby providing a measure of the model's performance.

\section{RESULTS}

\section{Landscape scale}

According to the spatial variables, the best fitting of the spatial terms included the cubic function of latitude and the combined linear function of longitude and the quadratic function of latitude as the best predictors. According to climatic and topographic variables, the model showed that the probability of occurrence of Bonelli's Eagles increased with the ruggedness of the terrain by including the slope of the UTM square as a significant predictor in the model (Table 2). The presence of Golden Eagles in the sampling unit was not included as a predictor of the occurrence of Bonelli's Eagles in the models.

According to the land-use subset of variables (second level of CLC classes), the model showed that the probability of occurrence increased non-linearly, reaching the maximum probability of occurrence at intermediate levels of the surface of arable land (estimate $=0.43 ; P=$ 0.007 ) and shrubland vegetation (estimate $=0.58 ; P=$ 0.001 ). This model explained $13.74 \%$ of total deviance. Using the first level of CLC classes, the probability of occurrence decreased with the surface of artificial areas. In this case, the model explained $11.12 \%$ of total deviance (Table 2).

The analysis of bioclimatic data showed that the probability of finding a square occupied by Bonelli's Eagles in Sicily decreased with the mean value of bioclimatic index (estimate $=-0.53 ; P=0.001$ ) and the value of evapo-transpiration in July (estimate $=-0.252 ; P=$ 0.001 ), and that the distribution of this species probably reflected the latitude gradient of bioclimatic transition zones.

Hierarchical partitioning of the variance showed that the largest fraction of the variability $(40.73 \%$ of explained variance) in Bonelli's Eagles' habitat preferences was accounted for by the effect of the spatial components, followed by the climatic and topographic variables (38.44\% of explained variance) (Fig. 2a). The effect of land-use was negligible, while the joint effect of spatial component + land-use variables accounted for $27.46 \%$ of the total variance.

Model performance was satisfactory. The best model at landscape scale showed a success rate (i.e. cases correctly predicted) of $87.20 \%$ (79.76\% and $94.63 \%$ of presences and absences correctly predicted, respectively). After the jackknife procedure, the success rate was $87.39 \%(94.46 \%$ and $80.32 \%$ of presences and absences being correctly predicted).

\section{Home-range scale}

The best fitting of the spatial terms showed only the cubic function of longitude as the best predictor. According to land-use variables, the model showed that the probability of finding an occupied territory of Bonelli's Eagles in Sicily decreased with the surface occupied by vineyards. In this case, the model explained $43.54 \%$ of total deviance (Table 2). The most parsimonious model showed that the probability of occurrence increased with CLC dominance and with surface of the largest patch/home-range surface (LPA; see variables' descriptions in Table 1). The GLM including the mosaic subset of variables explained $50.13 \%$ of the total deviance (Table 2). Considering the topographic and road subset, the model showed that the probability of finding occupied territories increased with the range of slope, which is related to the ruggedness of the terrain and thus to the availability of cliffs for nesting, explaining $37.33 \%$ of the total deviance (Table 2).

Hierarchical partitioning of the variance showed that, at this scale, the largest proportion of the variability $(33.67 \%)$ in the habitat preferences of Bonelli's Eagles was accounted for by the joint effect of mosaic + topographic and road density variables, followed by the joint effect of spatial components + topographic and road density variables (22.01\%) (Fig. 2b). The most important pure effect was accounted for by the mosaic and land-use variables (19.28\%).

At this scale, model performance was also satisfactory. The best model at home-range scale showed a success rate of $88.64 \%(90.91 \%$ and $86.36 \%$ of presences and absences correctly predicted, respectively). After the jackknife procedure, the success rate was also high $88.74 \%$ (86.68\% and $90.80 \%$ of presences and absences being correctly predicted).

\section{DISCUSSION}

We used data on the presence of Bonelli's Eagles in Sicily to achieve a better understanding of habitat preferences of this species and to identify the predictors of suitable areas for conservation in the island. Our results showed a significant spatial auto-correlation effect at landscape and home-range scales. This may correspond to the 
Table 2. GLM estimates and significance (Wald test) showing the probability of occurrence of Bonelli's Eagle in Sicily.

\begin{tabular}{|c|c|c|c|c|c|c|c|c|c|}
\hline Scale & Subset & Estimate & se & Wald & $P$ & $\mathrm{AlC}_{\mathrm{C}}$ & $d f$ & L ratio $\chi^{2}$ & $P$ \\
\hline \multirow[t]{3}{*}{ Landscape } & $\begin{array}{l}\text { Climatic and topographic } \\
\text { Intercept } \\
\text { Slope range } \\
y^{3} \\
x y^{2} \\
\text { Residual deviance }\end{array}$ & $\begin{array}{l}-6.050 \\
0.090 \\
-0.941 \\
-1.113 \\
46.34(21.54 \%)\end{array}$ & $\begin{array}{l}0.907 \\
0.016 \\
0.202 \\
0.200\end{array}$ & $\begin{array}{l}44.523 \\
33.346 \\
21.617 \\
30.950\end{array}$ & $\begin{array}{l}<0.001 \\
<0.001 \\
<0.001 \\
<0.001\end{array}$ & 275.938 & 3 & 77.966 & $<0.001$ \\
\hline & $\begin{array}{l}\text { Land use I CLC } \\
\text { Intercept } \\
\text { Artificial areas (1) } \\
x y^{2} \\
\text { Residual deviance }\end{array}$ & $\begin{array}{l}-1.070 \\
-0.473 \\
-0.782 \\
52.50(11.12 \%)\end{array}$ & $\begin{array}{l}0.151 \\
0.220 \\
0.151\end{array}$ & $\begin{array}{r}50.082 \\
4.623 \\
26.961\end{array}$ & $\begin{array}{r}<0.001 \\
0.032 \\
<0.001\end{array}$ & 316.248 & 2 & 35.655 & $<0.001$ \\
\hline & $\begin{array}{l}\text { Land use II CLC } \\
\text { Intercept } \\
\text { Arable land (21) } \\
\text { Shrub and herb (32) } \\
y^{3} \\
x^{2} \\
\text { Residual deviance }\end{array}$ & $\begin{array}{l}-1.215 \\
0.431 \\
0.588 \\
-0.417 \\
-1.121 \\
50.96(13.74 \%)\end{array}$ & $\begin{array}{l}0.174 \\
0.160 \\
0.180 \\
0.188 \\
0.213\end{array}$ & $\begin{array}{r}48.898 \\
7.290 \\
10.709 \\
4.915 \\
27.694\end{array}$ & $\begin{array}{r}<0.001 \\
0.007 \\
0.001 \\
0.027 \\
<0.001\end{array}$ & 306.747 & 4 & 49.156 & $<0.001$ \\
\hline Home range & $\begin{array}{l}\text { Land use III CLC } \\
\text { Intercept } \\
\text { Vineyards (221) } \\
x^{3} \\
\text { Residual deviance }\end{array}$ & $\begin{array}{l}-0.087 \\
-1.602 \\
-2.071 \\
6.20(43.54 \%)\end{array}$ & $\begin{array}{l}0.410 \\
0.588 \\
0.612\end{array}$ & $\begin{array}{r}0.045 \\
7.421 \\
11.438\end{array}$ & $\begin{array}{l}0.831 \\
0.006 \\
0.001\end{array}$ & 44.159 & 2 & 22.838 & $<0.001$ \\
\hline & $\begin{array}{l}\text { Mosaic } \\
\text { Intercept } \\
\text { Do } \\
\text { LPA } \\
x^{3} \\
\text { Residual deviance }\end{array}$ & $\begin{array}{l}-39.270 \\
11.059 \\
27.730 \\
-1.709 \\
5.48(50.13 \%)\end{array}$ & $\begin{array}{r}15.324 \\
4.223 \\
11.504 \\
0.630\end{array}$ & $\begin{array}{l}6.567 \\
6.857 \\
5.811 \\
7.359\end{array}$ & $\begin{array}{l}0.010 \\
0.009 \\
0.016 \\
0.007\end{array}$ & 38.322 & 3 & 30.674 & $<0.001$ \\
\hline & $\begin{array}{l}\text { Topographic and road } \\
\text { Intercept } \\
\text { Slope range } \\
x^{3} \\
\text { Residual deviance }\end{array}$ & $\begin{array}{l}-0.150 \\
2.196 \\
-0.890 \\
6.89(37.33 \%)\end{array}$ & $\begin{array}{l}0.421 \\
0.725 \\
0.440\end{array}$ & $\begin{array}{l}0.127 \\
9.179 \\
4.093\end{array}$ & $\begin{array}{l}0.721 \\
0.002 \\
0.043\end{array}$ & 42.420 & 2 & 24.580 & $<0.001$ \\
\hline
\end{tabular}

The percentage of explained deviance is indicated in parentheses; AIC was used to select the best model; CLC, CORINE land cover; Do, CLC dominance; LPA, largest patch area (see Table 1 for full definitions). 
(a)

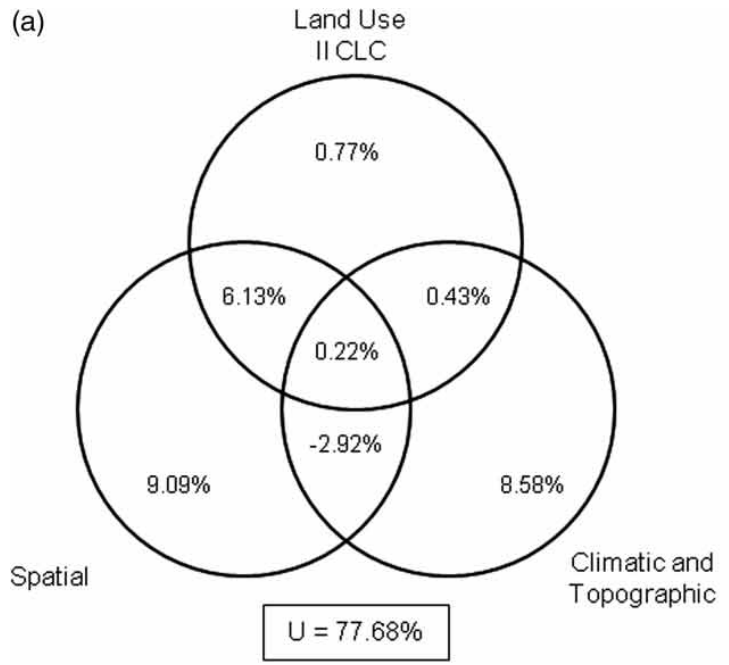

(b)

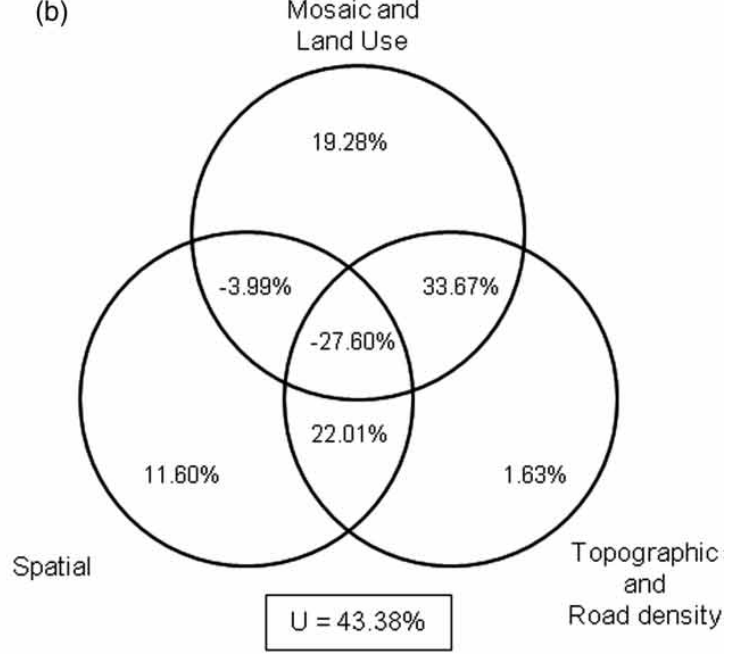

Figure 2. Hierarchical partitioning analysis of the probability of occurrence of a breeding territory of Bonelli's Eagles in Sicily, southern Italy. Models were computed at landscape scale (a) and home range scale (b).

Percentage of deviance explained by each component of the partition is presented; CLC, coordination of information on the environment (CORINE) land cover; $U$, unexplained variance.

latitudinal and longitudinal distribution of sites, implying that the population of Bonelli's Eagles is not randomly distributed across space in Sicily (Fig. 1). As cliff availability is often correlated with the slope and ruggedness of the terrain (Carrete et al. 2000, Balbontín 2005, Muñoz et al. 2005, López-López et al. 2006), it is likely that the observed high preference for sloping land actually reflects the availability of cliffs for nesting (Ontiveros \& Pleguezuelos 2003, Muñoz et al. 2005, López-López et al. 2006). Interestingly, the presence of potential competitors such as Golden Eagles was not included in the best models, indicating that they do not seem to have any effect on the occurrence of Bonelli's Eagles at the landscape scale. This could be because of the low density at which both eagles occur in Sicily (Di Vittorio 2007).

According to bioclimatic characteristics, $74 \%$ of the species' occurrence in UTM cells fell within the xeric belt from the upper dry thermo-Mediterranean horizon to the lower humid thermo-Mediterranean (RivasMartínez et al. 1987). The remaining 26\% of Bonelli's Eagle occurrence ranged from the lower dry meso-Mediterranean to the upper humid meso-Mediterranean. Our results confirmed previously described preferences of Bonelli's Eagles for warmer and drier environments with hot summers (Ontiveros \& Pleguezuelos 2003, Muñoz et al. 2005) and the preference for open areas (Carrete et al. 2002). The most parsimonious explanatory landscape model suggested that Bonelli's Eagles avoid artificial areas and prefer breeding sites surrounded by patches of natural (shrubs and/or herbaceous vegetation associations) and extensive agricultural habitats.

Bonelli's Eagles can tolerate a certain degree of human presence (Gil-Sánchez et al. 1996, Carrete et al. 2002, López-López et al. 2004, López-López et al. 2006) and their tolerance to human proximity is higher than that observed for other cliff-nesting raptors (López-López et al. 2007b). However, the negative relationship between artificial areas and the presence of Bonelli's Eagles in Sicily showed that human presence could represent an important factor of threat that could jeopardize the conservation of this insular population. For example, we have evidence of the serious effect of human disturbance on the reproductive output of Bonelli's Eagles, caused mainly by road or trail opening in natural areas, works and human presence in proximity of nesting sites, as well as the lack of any control in natural preserves where the species breeds (Di Vittorio 2007). As a result, at least 17 pairs failed breeding in the last 11 years. Furthermore, Bonelli's Eagles currently suffer high adult mortality in Sicily 1 10.20\% [Di Vittorio 2007]), and even the human pressure has caused the abandonment of traditionally occupied territories in recent decades. As suggested by other authors (Ontiveros \& Pleguezuelos 2003, Gil-Sánchez et al. 2004, López-López et al. 2006) our analyses confirmed the species' preference for agricultural areas (specially cereal pseudo-steppe areas in the case of Sicily), where the landscape is dominated by mixed and natural Mediterranean vegetation - mainly shrubland areas. This 
may be related to the relatively high availability and richness of prey species in those areas (López-López \& Urios 2010). In fact, the most representative prey in the diet of Bonelli's Eagles in Sicily was the Common Rabbit Oryctolagus cuniculus (37.2\% of prey items), followed by Rock Dove Columba livia (31.8\%) (Di Vittorio et al. 2001). Open areas, such as shrubland and pseudosteppe landscape, had in fact higher densities of the main prey species of this raptor, such as rabbits (Penteriani et al. 2003, Gil-Sánchez et al. 2004, Moleón et al. 2009, Moleón et al. 2011) and had a vegetative structure which allows an easier detection and capture of prey animals than closed-structure habitat, such as forests (Carrete et al. 2002, Penteriani et al. 2003).

At the home-range level, our results show a negative relationship between nest-site presence and the surface of vineyards, confirming that the species avoids intensive agricultural systems (Carrete et al. 2002). The model showed the preference for areas where there was a rather high mosaic of the aforementioned CLC classes, as expressed by the following indexes: 'Do', which is a measure of the existence of a CLC class more dominant in the sample unit; and LPA, which is the surface of the largest patch within the sample unit - both are measures of habitat herterogeneity (see full details about mosaic variables in Table 1). In the Mediterranean region (at least in Spain, France and southern Italy), the continuing interactions between ecosystems and humans through constantly evolving land-use practices have created particular landscapes in which the combination of many habitats in varying stages of regeneration and degradation occur together (Blondel \& Aronson 1999), creating the typical mosaic of habitats preferred by this raptor for nesting (López-López et al. 2006). This, in turn, emphasizes the importance of habitat heterogeneity (i.e. the existence of a number of habitat types at different habitat patches) in Mediterranean ecosystems, which is a major determinant of biological richness (Tews et al. 2004, López-López et al. 2011).

From a conservation point of view, our models suggest that the habitat preferences of Bonelli's Eagles for lower open areas surrounded by agricultural landscape implies a fairly high level of overlap between the eagles' homeranges and human activities and buildings. As towns, villages and other infrastructure increase, and agricultural intensification increases inland, anthropogenic pressures on breeding Bonelli's Eagles could become unsustainable in the long-term. Therefore, the overall Sicilian population could be exposed to threats that put its survival at risk. Dry cereal fields are the landscapes most frequently used by Bonelli's Eagles in Sicily (Di Vittorio 2007). They are also used by other endangered raptors such as Lesser Kestrels Falco naumanni and the endangered Egyptian Vultures Neophron percnopterus (Sarà \& Di Vittorio 2003, Mascara \& Sarà 2006). Therefore, it is necessary to take appropriate conservation measures to reduce these threats, especially regarding the preservation of extensively farmed arable and cereal patches (mainly croplands) and stopping the intensification of agricultural practices, as has been suggested in other European countries (Real \& Mañosa 1997, GilSánchez et al. 2004). This would allow the maintenance of the habitats preferred by Bonelli's Eagles for their foraging and for dispersal (Real \& Mañosa 1997, GilSánchez et al. 2004, Cadahía et al. 2010).

The small population size and insularity increases the probability of extinction of the Sicilian population of Bonelli's Eagles, owing to loss of genetic variability, demographic endogamy, environmental stochasticity, and risk of catastrophic events (López-López \& Di Vittorio, unpubl. data). In addition, the probability of recolonization is very low (or even absent) taking into account the lack of healthy populations nearby that could act as a potential source of individuals (Soutullo et al. 2008). Furthermore, in recent years, the species is becoming increasingly vulnerable as human disturbance and development of inland areas increases. Therefore, this makes the Sicilian population highly vulnerable. Finally, the lack of any specific conservation plan for Bonelli's Eagles in Sicily, in spite of their national and European conservation concern, is a cause of great concern. We consider that only the development of concrete and urgent actions can save this population from a slow but certain decline in the near future.

\section{ACKNOWLEDGEMENTS}

We would like to thank S. Grenci, V. Mannino and A. Ciaccio for their help during fieldwork and data collection during the study period. J. Balbontín and an anonymous referee made valuable suggestions that helped to improve the paper. P. L-L is supported by a 'Juan de la Cierva' postdoctoral grant of the Spanish Ministry of Economy and Competitiveness (reference JCI-2011-09588). Partial funding was provided by the ex-60\% grant University of Palermo for the year 2007. This paper complies with the current laws in Italy.

\section{REFERENCES}

Agenzia per la protezione dell'ambiente e per i servizi tecnici (APAT) 2005. La realizzazione in Italia del progetto europeo Corine Land Cover 2000. APAT Report No. 36 Rome Italy. 
Akaike, H. 1973. Information theory and an extension of the maximum likelihood principle. In Petrov, B.N. \& Csaki, F. (eds), Second International Symposium on Information Theory: 267-281. Akadémia Kiadó, Budapest, Hungary.

ARPA Sicilia 2008. Atlante della Biodiversità della Sicilia: Vertebrati Terrestri. ARPA Sicilia, Palermo, Italy.

Arrigoni Degli Oddi, E. 1929. Ornitologia Italiana. Hoepli, Milan, Italy.

Balbontín, J. 2005. Identifying suitable habitat for dispersal in Bonelli's eagle: an important issue in halting its decline in Europe. Biol. Conserv. 126: 74-86.

Balbontín, J., Penteriani, V. \& Ferrer, M. 2003. Variations in the age of mates as an early warning signal of changes in population trends? The case of Bonelli's eagle in Andalusia. Biol. Conserv. 109: 417-423.

BirdLife International 2004. Birds in Europe: Population Estimates, Trends and Conservation Status. BirdLife International, Cambridge, UK.

BirdLife International 2011. IUCN Red List for birds. Available at: http://www.birdlife.org (accessed 22 December 2011)

Blondel, J. \& Aronson, J. 1999. Biology and Wildlife of the Mediterranean Region. Oxford University Press, Oxford, UK.

Borcard, D., Legendre, P. \& Drapeau, P. 1992. Partialling out the spatial component of ecological variation. Ecology 73: 1045-1055.

Bosch, R., Real, J., Tintó, A., Zozaya, E.L. \& Castell, C. 2010. Home-ranges and patterns of spatial use in territorial Bonelli's Eagles. Aquila fasciata. Ibis 152: 105-117.

Bustamante, J. 1997. Predictive models for lesser kestrel Falco naumanni distribution, abundance and extinction in southern Spain. Biol. Conserv. 80: 153-160.

Bustamante, J. \& Seoane, J. 2004. Predicting the distribution of four species of raptors (Aves: Accipitridae) in southern Spain: statistical models work better than existing maps. J. Biogeogr 31 : 295-306.

Cadahía, L., López-López, P., Urios, V. \& Negro, J.J. 2010. Satellite telemetry reveals individual variation in juvenile Bonelli's eagle dispersal areas. Eur. J. Wildlife Res. 56: 923-930.

Carrete, M., Sánchez-Zapata, J.A. \& Calvo, J.F. 2000. Breeding densities and habitat attributes of Golden Eagles in south-eastern Spain. J. Raptor Res. 34: 48-52.

Carrete, M., Sánchez-Zapata, J.A., Martínez, J.E., Sánchez, M.A. \& Calvo, J.F. 2002. Factors influencing the decline of Bonelli's eagle Hieraaetus fasciatus in southern Spain: demography, habitat or competition? Biodivers. Conserv. 11: 975-985.

Carrete, M., Grande, J.M., Tella, J.L., Sánchez-Zapata, J.A., Donázar, J.A., Díaz- Delgado, R. \& Romo, A. 2007. Habitat, human pressure, and social behavior: partialling out factors affecting large-scale territory extinction in an endangered vulture. Biol. Conserv. 136: 143-154.

Channell, R. \& Lomolino, M.V. 2000. Dynamic biogeography and conservation of endangered species. Nature 403: 84-86.

Cortone, P. \& Mirabelli, P. 1984. Situazione dei rapaci in Calabria dal 1964 al 1984. Supplemento alle Ricerche di Biologia della Selvaggina 12: 57-65.

Cramp, S. \& Simmons, K.E.L. 1980. The Birds of the Western Palearctic. Oxford University Press, Oxford, UK.

Di Vittorio, M. 2007. Biologia e conservazione di cinque specie di uccelli rapaci in Sicilia. Università degli Studi di Palermo, PhD Thesis.

Di Vittorio, M., Grenci, S. \& Campobello, D. 2001 . Nuovi dati sulla biologia alimentare dell'aquila di Bonelli (Hieraaetus fasciatus) durante il periodo riproduttivo. Riv. Ital. Orn. 71 : 3-7.

Doderlein, P. 1869. Avifauna del Modenese e della Sicilia. Giorn. Sci. Nat. Econom. Palermo, Italy, Avilable from: http://books.google.it/ books?id=7FkaAAAAYAAJ\&printsec=frontcover\&hl=es\#v=onepage \&q\&f=false.
European Environmental Agency 2000. Corine Land Cover Technical Guide Addendum 2000. European Environmental Agency. Available at: http://www.eea.europa.eu/publications/tech40add (accessed 22 December 2011).

Forman, R.T.T. 1995. Land Mosaics: The Ecology of Landscapes and Regions. Cambridge University Press, Cambridge, UK.

Gil-Sánchez, J.M., Molino-Garrido, F. \& Valenzuela-Serrano, G. 1996. Selección de hábitat de nidificación por el Aquila perdicera (Hieraaetus fasciatus) en Granada. Ardeola 43: 189-197.

Gil-Sánchez, J.M., Moleón, M., Otero, M. \& Bautista, J. 2004. A nine-year study of successful breeding in a Bonelli's eagle population in southeast Spain: a basis for conservation. Biol. Conserv. 118: 685-694.

Gotelli, N. \& Ellison, A.M. 2004. A primer of Ecological Statistics. Sinaver Associates, Sunderland, MA.

Graf, R.F., Bollmann, K., Suter, W. \& Burgmann, H. 2005. The importance of spatial scale in habitat models: capercaillie in the Swiss Alps. Landscape Ecol. 20: 703-717.

Guisan, A. \& Zimmermann, N.E. 2000. Predictive habitat distribution models in ecology. Ecol. Model. 135: 147-186.

Hagemeijer, C. \& Blair, M.J. 1997. The EBCC Atlas of European Breeding Birds: Their Distribution and Abundance. T \& AD Poyser, London.

Hosmer, D.W. \& Lemeshow, S. 2000. Applied Logistic Regression Analysis, 2nd edn. Wiley \& Sons, New York.

Johnson, D.H. 1980. The comparison of usage and availability measurements for evaluating resource preference. Ecology 61: 65-71.

Keating, K.A. \& Cherry, S. 2004. Use and interpretation of logistic regression in habitat selection studies. J. Wildl. Manage. 68: 774-789.

Larson, M.A., Thompson, F.R. III, Millspaugh, J.J., Dijak, W.D. \& Shiey, S.R. 2004. Linking population viability, habitat suitability, and landscape simulation models for conservation planning. Ecol. Model 180: 103-118.

Legendre, P. \& Legendre, L. 1998. Numerical Ecology. Elsevier Science, Amsterdam, The Netherlands.

Levin, A.S. 1992. The problem of pattern and scale in Ecology. Ecology 73: 1943-1967.

Lo Valvo, M. \& Massa, B. 1992. Aquila del Bonelli Hieraaetus fasciatus (Vieillot, 1822). In Brichetti, P., De Franceschi, P. \& Baccetti, N. (eds), Fauna d'Italia XXIX, Aves I: 616-621. Edizioni Calderini, Bologna, Italy.

López-López, P. \& Urios, V. 2010. Use of digital trail cameras to study Bonelli's eagle's diet during the nestling season. Ital. J. Zool. 77: 289-295.

López-López, P., García-Ripollés, C., García-López, F., Aguilar, J.M. \& Verdejo, J. 2004. Patrón de distribución del Águila Real (Aquila chrysaetos) y del Águila-azor perdicera (Hieraaetus fasciatus) en la provincia de Castellón. Ardeola 51 : 275-283.

López-López, P., García-Ripollés, C., Aguilar, J.M., GarcíaLópez, F. \& Verdejo, J. 2006. Modelling breeding habitat preferences of Bonelli's eagle (Hieraaetus fasciatus) in relation to topography, disturbance, climate and land use at different spatial scales. J. Ornithol. 147: 97-107

López-López, P., García-Ripollés, C., Soutullo, A., Cadahía, L. \& Urios, V. 2007a. Are Important Bird Areas and Special Protected Areas enough for conservation? The case of Bonelli's eagle in a Mediterranean area. Biodivers. Conserv. 16: 3755-3780.

López-López, P., García-Ripollés, C., Soutullo, A., Cadahía, L. \& Urios, V. 2007b. Identifying potentially nesting habitat for golden eagles (Aquila chrysaetos) applied to Important Bird Areas design. Anim. Conserv. 10: 208-218. 
López-López, P., García-Ripollés, C. \& Urios, V. 2007c. Population size, breeding performance and territory quality of Bonelli's Eagle (Hieraaetus fasciatus) in eastern Spain. Bird Study 54: 335-342.

López-López, P., Maiorano, L., Falcucci, A., Barba, E. \& Boitani, L. 2011. Hotspots of species richness, threat and endemism for terrestrial vertebrates in SW Europe. Acta Oecologica 37: 399-412.

Martínez, J.E., Serrano, D. \& Zuberogoitia, I. 2003. Predictive models of habitat preferences for the Eurasian eagle owl Bubo bubo. A multiscale approach. Ecography 26: 21-28.

Mascara, R. \& Sarà, M. 2006. Densità e biologia riproduttiva del Grillaio. Falco naumanni, nella piana di Gela (Sicilia). Avocetta 30: 51-59.

Massa, B. 1985. Atlas Faunae Siciliae: Aves. Naturalista Siciliano, 9: $1-242$.

Massa, B. \& Schenk, H. 1983. Similarità tra le avifaune della Sicilia, Sardegna e Corsica. Lav. Soc. Ital. Biogeografia 8: 757-799.

McCullagh, P. \& Nelder, J.A. 1989. Generalized Linear Models. Chapman \& Hall, London.

Moleón, M., Sánchez-Zapata, J.A., Real, J., García-Charton, J.A., Gil-Sánchez, J.M., Palma, L., Bautista, J. \& Bayle, P. 2009. Large-scale spatio-temporal shifts in the diet of a predator mediated by an emerging infectious disease of its main prey. J. Biogeogr. 36: 1502-1515.

Moleón, M., Sánchez-Zapata, J.A., Gil-Sánchez, J.M., BareaAzcón, J.M., Ballesteros-Duperón, E. \& Virgós, E. 2011 1. Laying the foundations for a human-predator conflict solution: assessing the impact of Bonelli's eagle on rabbits and partridges. PLOSone 6: e22851.

Muñoz, A.R., Real, R., Barbosa, A.M. \& Vargas, J.M. 2005. Modelling the distribution of Bonelli? s eagle in Spain: implications for conservation planning. Divers. Distrib. 11 : 477-486.

Nams, V.O., Mowat, G. \& Panian, M.A. 2006. Determining the spatial scale for conservation purposes - an example with grizzly bears. Biol. Conserv. 128: 109-119.

Niamir, A., Skidmore, A.K., Toxopeus, A.G., Muñoz, A.R. \& Real, R. 2011 . Finessing atlas data for species distribution models. Divers. Distrib 17: 1173-1185.
Ontiveros, D. 1999. Selection of nest cliffs by Bonelli's Eagle (Hieraaetus fasciatus) in southern Spain. J. Raptor Res 33: 110-116.

Ontiveros, D. \& Pleguezuelos, J.M. 2003. Physical, environmental and human factors influencing productivity in Bonelli's eagle Hieraaetus fasciatus in Granada (SE Spain). Biodivers. Conserv. 12: 1193-1203.

Penteriani, V., Balbontín, J. \& Ferrer, M. 2003. Simultaneous effects of age and territory quality on fecundity in Bonelli's Eagle. Hieraaetus fasciatus. Ibis 145: E77-E82.

Real, J. \& Mañosa, S. 1997. Demography and conservation of western European Bonelli's eagle Hieraaetus fasciatus populations. Biol. Conserv. 79: 59-66.

Rivas-Martínez, S. 1987. Memoria del Mapa de Series de Vegetación de España. ICONA, Madrid, Spain.

Robertson, M.P., Peter, C.I., Villet, M.H. \& Ripley, B.S. 2003. Comparing models for predicting species' potential distribution: a case study using correlative and mechanistic predictive modelling techniques. Ecol. Model. 164: 153-167.

Rushton, S.P., Ormerod, S.J. \& Kerby, G. 2004. New paradigms for modelling species distributions? J. App. Ecol. 41: 193-200.

Sarà, M. 2008. Breeding abundance of threatened raptors as estimated from occurrence ddata. Ibis 150: 766-778.

Sarà, M. \& Di Vittorio, M. 2003. Factors influencing the distribution, abundance and nest-site selection of an endangered Egyptian vulture (Neophron percnopterus) population in Sicily. Anim. Conserv. 6: 317-328.

Soutullo, A., López-López, P. \& Urios, V. 2008. Incorporating spatial structure and stochasticity in endangered Bonelli's eagle's population models: implications for conservation and management. Biol. Conserv. 141: 1013-1020.

Store, R. \& Jokimäki, J. 2003. A GIS-based multi-scale approach to habitat suitability modelling. Ecol. Model. 169: 1-15.

Tews, J., Brose, U., Grimm, V., Tielbörger, K., Wichmann, M., Schwager, C.M. \& Jeltsch, F. 2004. Animal species diversity driven by habitat heterogeneity/diversity: the importance of keystone structures. J. Biogeogr. 31: 79-92.

Whitfield, J. 2005. Is everything everywhere? Science 310: 960-961. 